The Historical foumal, 46, 4 (2003), pp. $935^{-952}$ (C) 2003 Cambridge University Press

DOI: Io.Ior7/Soor8246Xo3003376 Printed in the United Kingdom

\title{
THE ORIGINS OF SOE IN FRANCE*
}

\author{
CHR I S T O PHER J. MURPH Y \\ University of Reading
}

\begin{abstract}
A B S T R ACT. This article explores the official motivation behind the authorization in Ig6o of research into the activities of the Special Operations Executive (SOE) during the Second World War by M. R. D. Foot, leading to the publication of SOE in France in 1966. The work has traditionally been viewed as the official response to critical investigative works on SOE published during the 1950s, combined with the vocal campaign of Dame Irene Ward, who made several calls in the House of Commons for an official account of SOE to be published. Material now available at the Public Record Office reveals that these were not the sole considerations in official minds, nor the most significant, concerning the possibility of publishing such a work. The foreign office was particularly concerned that Britain's contribution to wartime resistance in Europe, exemplified by SOE, was being overshadowed by both soviet propoganda, emphasizing the communist contribution to resistance, and the publicity being given to SOE's American counterpart, the Office of Strategic Services (OSS). The 'campaign' of Dame Irene Ward, supported by the negative slant given to SOE in the books of Jean Overton Fuller and Elizabeth Nicholas, unknowingly gave support to a frame of mind that was already in existence in favour of an unofficial account of SOE activity, albeit for different reasons.
\end{abstract}

The publication in I966 of M. R. D. Foot's SOE in France represented an unprecedented moment for historians of the British intelligence community. The book details the activities in France of the Special Operations Executive (SOE), the organization established in I940 with responsibility for sabotage and subversion throughout occupied Europe and beyond, and constitutes the first officially sponsored account of a British secret service made available to the general public. It has been viewed as a triumph by those engaged in intelligence history, Christopher Andrew describing the work as the 'first major breach in the wall of Whitehall secrecy'. ${ }^{1}$ Starting work on the book in i96o, Foot was allowed to make use of the remaining SOE archive, which would remain closed to the public for a

* I would like to express my thanks to Dr Philip Murphy, for reading early drafts of this article and offering valuable advice. I am also grateful to Professor M. R. D. Foot for his comments. Thanks are also due to Helen Langley at the Bodleian Library for allowing access to the papers of Dame Irene Ward while they were being catalogued, and to Mr David J. Greenslade for permission to quote from them.

${ }^{1}$ Christopher Andrew, 'Historical research on the British intelligence community', in Roy Godson, (ed.), Comparing foreign intelligence: the US, the USSR, the UK and the Third World (London, I988), pp. 43-65, at p. 45 . 
further thirty-three years, ${ }^{2}$ and to interview a small number of ex-SOE personnel. The book was officially considered a 'companion volume to the official histories' of the Second World War, and described later by Foot himself as a 'quasi-official' history. ${ }^{3}$ This article aims to explore the origins of this unprecedented work, and the factors that led the authorities to commission archival research into SOE in Ig6o.

In the preface to the book, Foot gave a brief outline of its origins:

The project derives from the continuing concern expressed, both in parliament and outside it, that there should be an accurate and dispassionate account of SOE's activities in the war of 1939-1945. This concern led Harold Macmillan, while Prime Minister, to authorise some research. In the Foreign Office ... it was determined to find out whether a study could be written of what SOE did in France. ${ }^{4}$

This did not please Dame Irene Ward, Conservative MP for Tynemouth, who believed that she had played a significant role in the conception of SOE in France, which was worthy of acknowledgement. Dame Irene expressed this sentiment in a letter to Foot who, in response, tactfully suggested that 'it may be that, like me, you do not know all that has gone on behind the scenes on this whole Subject':

You claim that "The book's final publication arose from my efforts." I have deliberately said nothing specific about this, because I understand that you were pushing at an already open door. I did name Macmillan, because it was he who took the responsibility for authorising the start of the historical project. ${ }^{5}$

In response, Dame Irene wrote again to Foot, and set down her version of the book's origins:

Two years before we were fortunate enough to ask you to write the Book, I personally had sent Elizabeth Nicholas' Book 'DEATH BE NOT PROUD' and Jean Overton Fuller's book 'DOuble webs' to Harold Macmillan who was Prime Minister at the time. At that stage I had become rather cynical about all the Books that had been published ... I suggested to my Prime Minister that the time had come to authorise an official History of S.O.E. I knew this also to be the wish of leading Resistance workers in many of the European Countries ... I then saw my Prime Minister and he agreed with my view that the time for an official History had arrived, and he personally negotiated the $£ 5000$ with the

2 The first series of SOE files, focusing on activity in the Far East, was transferred to the Public Record Office in June i993.

${ }^{3}$ Burke Trend, 'The history of the Special Operations Executive in France', 3 Aug. I965, Public Record Office, Kew (PRO), PREM I3/949; M. R. D. Foot, Resistance (London, I976), p. xi. In a memo prepared for Harold Wilson, Trend noted that the book was not considered an official history 'in the full sense of the term' due to the fact that 'it has not been written by a team of historians, as are the ordinary official histories of the war, or subjected to the full process of departmental scrutiny which the official histories undergo'. Rather, it was classed as 'a companion volume to the official histories', prefaced 'with a statement that the author had had full access to all relevant material and was alone responsible for the opinions which he expressed'.

${ }^{4}$ M. R. D. Foot, SOE in France (HMSO, I966; second impression with amendments, I968), pp. ix-x.

5 Foot to Dame Irene, 2I Mar. I966, Oxford, Bodleian Library, Dame Irene Ward papers, MS.Eng.c.698o, fo. I9o. 
Treasury ... I have only been anxious that a proper description should be put in the Book just outlining how and why it was that the decision was taken. I desired no other comment of any kind and I am absolutely amazed at what you say. ${ }^{6}$

While Dame Irene's account is accurate, it does not tell the whole story of the origins of the book, which included factors far beyond her own efforts. In raising the question of a European desire for knowledge on SOE, Dame Irene touched briefly on the more substantive issue of the book's origins, a concern with the memory of wartime resistance in Europe, upon which this article will focus. Yet this was not a point Dame Irene emphasized, preferring instead to focus her attention on the scandals revealed by the likes of Jean Overton Fuller.

When the origins of SOE in France are discussed within the context of SOE historiography, the publication of investigative works about SOE and Dame Irene's subsequent intense lobbying for the project are highlighted, establishing an implicit cause and effect. Mark Seaman traces the history of SOE in France to the unofficial publications that flourished during the I95os, noting that 'controversial "investigative" works about SOE's F Section encouraged the Cabinet Office to commission an official history of SOE's activities in France', 7 the government deciding that such criticisms 'needed to be answered'. 8 The persistence of Dame Irene has been highlighted by Nigel West, who notes that 'Following more lobbying from Dame Irene, the Prime Minister ... authorised research to determine whether an official account of SOE's activities in France could be published. ${ }^{9}$

As with Dame Irene's account, the events chronicled are accurate, but incomplete. This is not, however, to imply undue criticism on the part of those who have written on the origins of SOE in France, as Dame Irene proceeded to take efforts to emphasize her part in the origins of the book. Following Foot's refusal to amend his preface, Dame Irene wrote to the Daily Telegraph, drawing attention to the 'major part in arranging for the history to be written' that she had made. ${ }^{10} \mathrm{In}$ Inside SOE, which shortly followed SOE in France into print, E. H. Cookridge also drew attention to Dame Irene's involvement in the origin of Foot's official account, while later, when preparing amendments for a new edition of Madeleine in I970, Jean Overton Fuller added an appendix outlining the origins of SOE in France which, again, portrayed Dame Irene as having played a significant part. ${ }^{11}$ Such comments have effectively served to misdirect attention from other, more

${ }^{6}$ Dame Irene to Foot, 25 Mar. 1966, Bodleian Library, Dame Irene Ward papers, MS.Eng.c.698o, fo. $188-9$.

7 Mark Seaman, 'Founding father? Sir Colin Gubbins and the origins of SOE', Intelligence and National Security, I I (I996), pp. 360-3, at p. 360.

8 Idem, 'Landmarks in defense literature', Defense Analysis, 3 (I987), pp. I9I-3, at p. I9I.

9 Nigel West, Secret war (London, I992), p. 4.

10 Daily Telegraph, letters to the editor, 29 Apr. I966.

11 Cookridge noted that 'the Prime Minister, Mr Harold Macmillan, vigorously prompted by Dame Irene Ward, M.P., had decided that an official history of SOE in France should be produced' (E. H. Cookridge, Inside SOE (London, I966), p. xiii). For further details on Overton Fuller's appendix to Madeleine, see PRO, PREM I5/I43. 
long-term, considerations: there is much to support Foot's suggestion that Dame Irene's knowledge was more limited than she herself thought, and that both Dame Irene's persuasive powers and the significance of the critical books on SOE published during the I950s have been taken out of context.

Throughout the I950s, a new, more critical picture of SOE was being painted, which burst the balloon of the 'upbeat, charming, ironic, modestly self-effacing' memoir literature that had appeared following the end of the war. ${ }^{12} \mathrm{Jean}$ Overton Fuller and Elizabeth Nicholas turned their attention to SOE's French (F) Section, while Pieter Dourlein focused on SOE's disastrous activities in Holland. ${ }^{13}$ Such books attracted the attention of Dame Irene, who in February 1956 made the first of several calls in the House of Commons for the release of an official work on SOE. ${ }^{14}$ Following the publication of Overton Fuller's Double webs, Dame Irene wrote to the foreign secretary, Selwyn Lloyd, demanding an answer to what she saw as 'an outstanding question' contained in the book concerning the controversial SOE agent, Henri Dericourt. ${ }^{15}$ Dame Irene also wrote Macmillan, drawing attention to the 'quite substantial points' about SOE found in Nicholas's and Overton Fuller's books, noting that 'All I have asked for is that an objective book be written by someone in whom we should have confidence, the files being made available ${ }^{16}$ Dame Irene wrote again to Macmillan on 12 November, enclosing a copy of Double Webs and hinting at conspiracy: 'I wonder when the Foreign Office realise that it would have been advisable to have been just to those whose lives were sacrificed or whose reputations were tarnished rather than protect those who however inadvertently had contributed to these horrors. ${ }^{17}$ In his reply, Lloyd conceded that there was 'a good case for trying to arrange that the true facts about S.O.E. are known and that individual exploits are seen in proper perspective', and noted that the foreign office 'have this problem very much in mind' ${ }^{18}$ Macmillan's response was drafted along similar lines. He noted that 'I am inclined to think that the sort of book which you have in mind might be useful', and informed Dame Irene that Lloyd would arrange for further discussions to take place. ${ }^{19}$ Dame Irene subsequently met with Lord Lansdowne, joint parliamentary under-secretary of state at the foreign office, who later recorded that she had asked for permission 'to publish the Prime Minister's letter

12 Rita Kramer, Flames in the field (London, I995), p. 314.

13 Jean Overton Fuller, Madeleine (London, I952); idem, The Starr affair (London, I954); idem, Double webs (London, I958); Elizabeth Nicholas, Death be not proud (London, I958); Pieter Dourlein, Inside north pole (London, I953).

14 Hansard, oral answers, 22 Feb. I956, cols. 363-6.

15 Dame Irene to Lloyd, 29 Oct. I958, PRO, PREM II/5084.

16 Dame Irene to Macmillan, 3I Oct. I958, PRO, PREM I3/I047.

17 Dame Irene to Macmillan, I2 Nov. i958, PRO, PREM i I/5084.

18 Lloyd to Dame Irene, i2 Nov. I958, PRO, PREM i / 5084 .

19 Macmillan to Dame Irene, 25 Nov. I958, PRO, PREM II/5084. Macmillan emphasized his disdain for conspiracy theory: 'I really do not think that you would expect me to take seriously any suggestion that there has been some sort of conspiracy of silence about all this. I doubt if, in fact, it will ever be possible to establish exactly where praise or blame may have lain in all these intricate clandestine operations'. 
to her of November 25, or at any rate that part of it which dealt with the possibility of an official history', a proposal which she was 'eventually ridden off', being encouraged instead to ask a Parliamentary Question on the possibility of an official history of SOE. Lansdowne clearly linked the possibility of a publication with recent unofficial works on SOE, noting his hope that Dame Irene's question would:

provide an opportunity of suggesting that the publication of an official (or officially sponsored) history would help to dispose of the accusations which have been made by Mrs Nicholas, Miss Overton Fuller and others to the effect that S.O.E. was incompetently run and, either through negligence or even deliberately, sent agents to their death. ${ }^{20}$

Dame Irene duly asked the question in the Commons in December, in response to which the foreign secretary announced that 'the production of an account of these activities would be useful', and that the issue was 'being examined'. ${ }^{21}$

\section{I}

To the extent of bringing the question of a publication on SOE front and centre, Dame Irene did play a part in the origins of SOE in France. However, official minds had other concerns. Dame Irene's acknowledgement of European interest in wartime resistance points in the right direction, but the concern was not simply to satisfy a growing demand for information. Rather, it was recognized that the lack of information on SOE was allowing Britain's role to be forgotten, and others to take undue credit for resistance activity. In a letter written in June I959, Sir Edward Hale of the cabinet office historical section noted that the pressure for a book on SOE had 'developed on two fronts':

At home, books have been written which attribute to incompetence at S.O.E. the fate of certain agents who fell into the hands of the Gestapo, and there have been demands for an enquiry. It has been suspected that the reason why access to the records of S.O.E. has not been permitted to anyone ... is in order to shield people who ought to be brought to book. Apart from this, there is great and growing interest on the continent in the history of the resistance, and the absence of any official information about the part played by S.O.E. creates a bad impression there, and may prevent this country from obtaining the credit due to it for the help given to resistance. ${ }^{22}$

The question of the 'great and growing' interest in resistance throughout Europe has received scant attention in comparison to that given to Dame Irene, Overton Fuller et al., despite the fact that the available material suggests that this was a far more significant factor in the origins of SOE in France, as a paper written by Sir Patrick Dean, deputy under-secretary of state at the foreign office, made clear:

We ourselves do not take Dame Irene unduly seriously. If it were only a question of her, we could probably turn the proposal for an S.O.E. history down flat and ride out whatever

20 Report by Lansdowne on meeting with Dame Irene Ward, io Dec. I958, PRO, PREM i /5o84.

21 Hansard, written answers, II Dec. I958, col. I2I.

22 Hale to Trend, io June i959, PRO, T 220/I388. 
trouble she might then be able to make. As you know, however, there are solid arguments in favour of publishing an impartial and objective account of our achievements, if one can be written. ${ }^{23}$

What were these 'solid arguments' that favoured the publication of a history of SOE? When inter-departmental discussions over further SOE histories took place in I969, the issue of interest in resistance in Europe was explicitly defined as concern with the growing Communist appropriation of wartime resistance and recorded as the most significant of four factors that had led to the publication of SOE in France:

(i) to correct the impression being spread abroad at that time that the Communists alone amongst the allies had given real support to indigenous resistance movements in captured territories in Europe, including France after the collapse of that country's military effort in 1940 ;

(ii) to restore the balance of truth to stories already published about SOE divorced from their proper historical context;

(iii) to do justice to the courage of many SOE agents, alive and dead, who had played their part, in secret, in the final allied victory;

(iv) to respond in some measure to the demand, both in and out of Parliament at home and abroad, for release to the public of an objective account of SOE's wartime activities both in direct sabotage and in instigating and supporting indigenous resistance movements. $^{24}$

Concern at Communist interpretations of wartime resistance activity, it was maintained, had been considered more important than the need to counter unofficial accounts of SOE activity that appeared during the I950s, while the 'demand' for an official account, a thinly veiled reference to Dame Irene Ward's campaign, was relegated to last place, while room for ambiguity was removed later in the paper, which noted that:

It can be assumed that a few members of the House and a small section of the public will continue to exert intermittent pressure on Ministers to follow 'SOE in France' with other companion volumes ... It did not weigh heavily when the decision on 'SOE in France' was taken and should not do so now. The opinions of these MPs does not appear to command wide support in the House, and is, by virtue of human nature, bound to diminish with time. $^{25}$

Yet this paper can also be viewed as an attempt to rewrite recent events, as its post-publication analysis does not sit perfectly alongside the material from the late I950s and early ig6os now available at the Public Record Office, in which concern with countering communist propaganda is never explicitly linked to the possibility of commissioning and publishing SOE in France, while at the same time the fact remains that $S O E$ in France did appear after Dame Irene had launched her

23 Dean to Trend, 3 May i96o, PRO, PREM i / 5084 .

24 'PUSD Study of the pros and cons of publication of further histories of SOE in the light of experience gained since the decision to publish "SOE in France", , July I969, p. 2, PRO, CAB I03/570.

25 Ibid., p. 7 . 
campaign in support of such a book. There is also the quite conspicuous absence of concern over American versions of wartime resistance; file material reveals a greater - at least, more explicit - concern at the view of support given to the resistance emanating from the United States than from the Soviet Union.

\section{I I}

There is evidence to support the suggestion that the foreign office held long-term concerns over the issue of Britain, through SOE, gaining the credit it was due for work with the European resistance during the war, and to suggest that some form of officially sponsored product publicizing SOE would have eventually appeared regardless of Dame Irene's badgering. Such concern on the part of the foreign office dated back to the war itself: when SOE's vice chief, H. N. Sporborg (V/CD), approached the foreign office with details of a plan for the BBC to broadcast a programme on SOE, and for an SOE press conference to be held, the foreign office response was wholly enthusiastic:

We are very glad to hear that something is being done about this because it is getting more urgent both from the point of view of the America public, who have recently been told all about the exploits of the O.S.S. [Office of Strategic Services], and from the point of view of continental opinion which is rapidly forgetting what we have done to help the Resistance. ${ }^{26}$

The conference and publication of an accompanying press release were cancelled when the war office demanded the involvement of the chiefs of staff in the decision. Colin Gubbins, SOE's third and final executive head (CD), took advantage of the foreign office desire to publicize Britain's role in the European resistance, writing to Harold Caccia, deputy under-secretary, that 'the matter should be taken up directly by the Foreign Office with the Chiefs of Staff ... if you are still of the opinion that this country's effort should be made more widely known, particularly to the Continent'. ${ }^{27}$ The letter was accompanied by a covering note from Sporborg, which emphasized the point that 'the contribution which this country made to Resistance should not be overlooked or swamped by the propaganda of others'. Sporborg continued to note that 'It seems to me that the spate of publicity on this subject in the United States renders the question of giving publicity here more important and I really think that the proposed Press Conference might do a lot of good in this country, on the Continent, and even in the United States itself. ${ }^{28}$

The foreign office took the matter into its own hands. Sir Alexander Cadogan, permanent under-secretary, wrote to the secretary of the chiefs of staff committee, Major General L. C. Hollis, expressing the foreign office concern that consideration should be given to the question of whether, before SOE was

26 Bromley to Sporborg, 8 Oct. 45, PRO, HS 8/863. For further details on the immediate post-war attention given to OSS in America, see James I. Deutsch, "I was a Hollywood agent": cinematic representations of the Office of Strategic Services in I946', Intelligence and National Security, I3 (I998), pp. 85-99. 27 Gubbins to Caccia, 23 Oct. I945, PRO, HS 8/863.

28 Sporborg to Caccia, 9 Nov. I945, PRO, HS 8/863. 
disbanded, 'some publicity should be given to the assistance rendered by this country through S.O.E. to Resistance in occupied countries'. Cadogan emphasized foreign office support for the idea, pointing out that 'widespread publicity has been given to the exploits of O.S.S. and there may be some danger of opinion on the continent as well as in the U.S.A. forgetting the extent of British help' ${ }^{29}$ The scheme floundered as it did not receive the blessing of the joint intelligence committee (JIG), to which Hollis referred the matter. The foreign office concern over Britain's receiving due credit for the role it played assisting the resistance was dismissed, the committee agreeing that it was 'doubtful whether any useful purpose would be served to British interests abroad if such information were released in spite of the likelihood of further uninformed statements on the subject and of American publicity on behalf of O.S.S.'. The committee concluded that 'no release of information on the activities of S.O.E. should be made until there is a sufficient demand at home and abroad for such release' ${ }^{30}$ The comment is a significant one: effectively, even before the demise of SOE, the conditions governing the release of information relating to the organization had been put in place. Certainly, Dame Irene can be seen as contributing to the 'demand at home', but her campaign did not fulfil the entire criteria.

A further incident that sheds light on official attitudes towards publicizing SOE took place in early I958, highlighting the fact that the immediate post-war concern with America's appropriation of special operations had not been forgotten. In April, the war office prepared a memorandum for the security policy and methods committee (SPMC), a cabinet-based inter-departmental body with representatives from the foreign office, service departments, security service, and numerous other government departments as circumstances dictated. The memorandum noted that the war office had been approached by the Renown Picture Corporation, which requested 'assistance in obtaining material for a series of Television films, to be shown in America, based on S.O.E. activities during the last war'. The war office took this as an opportunity to revisit the whole question of policy regarding SOE publicity:

It is felt now that providing no information is released on the under-mentioned broad aspects we should view with sympathy any project, such as now put forward by the Renown Picture Corporation, which might result in advantageous propaganda and be prepared to give assistance in vetting scripts and providing advice as necessary:-

(a) Methods which might be useful in another war.

(b) Matters which might give offence to friendly powers or prejudice relations with them, or ex-neutrals.

(c) Details of equipment which is still SECRET. ${ }^{31}$

29 Cadogan to Hollis, I3 Nov. I945, PRO, CAB I2I/305.

30 Hollis to Chief of the Air Staff, First Sea Lord, Vice-chief of the Imperial General Staff, 27 Nov. I945, PRO, CAB I2 I/305.

${ }_{31} \mathrm{~S}(\mathrm{PM})\left(5^{8}\right)$ 32, Release of Information on the Activities of Special Operations Executive: memorandum by the war office, I4 Apr. 1958, PRO, CAB 2I/4523. 
The war office requested that the committee 'consider the extent to which it is advisable to assist or encourage the type of publicity envisaged, and to formulate a policy' ${ }^{32}$

Upon receipt of the memorandum, an official at the ministry of defence wrote to J. W. L. Shillidy, secretary of the SPMC, noting that the ministry of defence 'would support the idea of assisting the project put forward by the Renown Picture Corporation, particularly as the films are to be shown in the United States'. The letter revealed the ministry of defence's informed concern over America's version of wartime special operations:

There has been in recent years a steady stream of material about American activity in this field. There is indeed currently running in this country a series of television films based, allegedly, on the activities of O.S.S. From all this material the man in the street might well get the impression that the Americans were the only people in this field, and I am sure that it would be of advantage to us to help to correct that impression. ${ }^{33}$

The ministry of defence advocated 'unofficial' support; to 'arrange for the Company to employ as "adviser" someone who it is known was a member of S.O.E., who could supply them with material and, at the same time, act as a kind of "buffer" for security and other reasons between S.I.S., who I think maintain the records of S.O.E., and the Company' ${ }^{34}$ Shillidy discussed the matter with Burke Trend, at that point in his career deputy secretary to the cabinet, who believed that 'no great harm - and some good - may be done if we make our cooperation available'. However, he advised Shillidy to recommend to the SPMC that the matter be referred to the JIC. ${ }^{35}$

The SPMC discussed the matter on 18 April. At the outset, the SIS representative made it clear that 'his Department was very strongly opposed to any change in the existing policy of refusing access to S.O.E. records to everybody except officials in the course of their duty'. Nevertheless, during the ensuing discussion it was noted that there were 'appreciable propaganda and prestige advantages to be derived from the making of such films on this subject'. That such a move was intended to help counter stories of OSS activity was made clear when it was noted that the Renown Picture Corporation was proposing to use American actors: 'Prima facie such conditions were unacceptable to us. ${ }^{, 36}$ In conclusion, the committee agreed that there was 'a strong case for being more forthcoming' with information about SOE, providing that access to SOE's records remained limited to officials, that the source of the request was reputable, and that SIS would be 'invited to consider what form of assistance should be given'. The committee also agreed that 'they were not in a position to give a final ruling on this subject', and referred the matter to the JIC, to ascertain 'what further sanction should be sought for their recommendations' ${ }^{37}$

${ }^{32}$ Ibid. $\quad{ }^{33}$ J. A. Drew to Shillidy, I5 Apr. 1958, PRO, CAB 21/4523.

${ }^{34}$ Ibid. $\quad{ }^{35}$ Note for Record, B Trend, I8 Apr. I958, PRO, CAB 2I/4523.

${ }^{36}$ Minutes of the $4^{\text {th }}$ Meeting of the Security Policy and Methods Committee, Item 3, I8 Apr. I958, PRO, CAB 2I/4523. ${ }^{37}$ Ibid. 
Trend met with the chairman of the SPMC, Mr Samuel, on 25 April. Trend noted that the request for information 'supported the general thesis that there might be some advantage in our securing greater publicity for the part which S.O.E. played during the war' ${ }^{38}$ Samuel and Trend also discussed the latest letter from Dame Irene to the foreign secretary. Trend noted the letter 'suggests that as is evident in other connections - public interest in S.O.E. activities continues and that there is an almost inexhaustible appetite for war stories and films, particularly from the view of covert activities'. He went on to suggest that 'it would do no harm if the J.I.C. discussion was directed not merely to the particular issue of the films ... but to the rather wider question of our treatment of S.O.E. records as a whole', proposing that it be ascertained whether 'the J.I.C. felt that the time had now come when we could be more generous (though still highly selective) in granting access to the relevant papers'. If so, Trend believed that Professor William Mackenzie, who had earlier prepared an in-house history of SOE, should be approached and asked to act 'as a kind of unofficial adviser', noting that he 'has always felt that we should be rather more active in putting on public record our own part in the European resistance movement ${ }^{39}$

The JIC considered the matter on I5 May. A minute prepared by the secretary, which covered 'a memorandum by the Foreign Office which summarised the present position', has not yet been released into the public domain. However, the JIC minutes reveal that the meeting considered 'the security implications of the limited relaxation of the present rules', as advocated by the SPMC. During the ensuing discussion, the 'constant pressure from the press and members of the public for more information on this subject' was noted, as was SOE's existence as a purely wartime body. Providing that the interests of $\mathrm{MI}_{5}$ and SIS could be maintained, the committee believed that 'some relaxation of the existing rules should be possible'. In terms of releasing information, it was considered that a 'special staff', perhaps only one officer, would be necessary, as no consideration was given to providing direct access to the archives. In conclusion, the JIC emphasized that they 'were only competent to give an opinion on the security implications of this problem', and made no attempt to veto the suggestion, provided that any releases made were 'strictly limited to S.O.E.'s exploits in the last war', that areas that remained sensitive were not released, and that documentary material was provided through a special staff - a far cry from the refusal expressed by the committee in $1945 .{ }^{40}$ The subject was raised at a later JIC meeting during August, by which point 'the administrative arrangements necessary for dealing with such requests' had been finalized, but required ministerial approval before any further action could be taken. ${ }^{41}$ Ministerial approval for the move was granted later in the year, Trend referring to "the decision of Ministers that a controlled release of information about S.O.E. activities should now be permitted

\footnotetext{
38 Note for Record, B Trend, 25 Apr. I958, PRO, CAB 2I/4523.

39 Ibid.

40 JIC Minutes (JIC (58) 33rd Meeting), I5 May i958, PRO, CAB I59/29.

41 JIC Minutes (JIC (58) 56th Meeting), 2 I Aug. I958, PRO, CAB I59/30.
} 
for publicity purposes' in correspondence during November. ${ }^{42}$ There is no further material to indicate whether the request of the Renown Picture Corporation was met.

\section{V}

In addition to concern over the publicity given to the American OSS there is some, albeit less direct, evidence to support the claim made in I969 that countering Communist propaganda was the main purpose of the SOE history. In I948, the foreign office established its information research department (IRD), to devise means of combating Communist propaganda, with immediate priority being given to France and Italy. ${ }^{43}$ Concern with Italy continued into I949, when IRD drew attention to the manner in which wartime resistance was being rewritten from a Communist point of view, including Communist appropriation of the term 'partisan': 'One of the Communists' important efforts has been to attempt to arrogate themselves all the credit for Partisan activities in Italy, and consequently all control of such political force as is represented by ex-Partisan associations in the country now. ${ }^{44}$ When considering potential courses of action, the legacy of SOE was considered a useful means whereby IRD could launch a counter-attack. While the suggestion put forward was a far cry from a proposal to publish a book detailing SOE activity in Italy, it was proposed to emphasize SOE's role through a visit of ex-Italian partisans to Britain. The first head of IRD, Ralph Murray, who had worked for the political warfare executive (PWE) during the Second World War, outlined the idea in a letter dated I9 July:

it might be a good thing to supplement the rather meagre scheme of visits by Italians to the U.K. under Foreign Office auspices by a party of ex-partisans. There are, it appears, a considerable number of these in Italy who have feelings of loyalty towards British officers with whom they worked during the war and with whom they have remained on friendly terms.

Murray suggested that the Special Forces Club, founded at the end of the war by SOE veterans, should be asked whether they would 'be prepared to act as host to such a party, to make rather a fuss of them, produce some of their own friends and perhaps provide an opportunity for some considerable judicious publicity about the event' ${ }^{45}$ Col. Leslie Sheridan, one of Murray's earliest recruits to IRD and himself a 'former SOE psychological warrior', ${ }^{46}$ met with Gubbins, and reported that he was 'very willing to play', which greatly encouraged Sheridan who desired the co-operation of the Club to help ensure that there would be 'no trace of the hand of H.M.G. in the matter', ${ }^{47}$

42 Trend to de Zulueta, I2 Nov. I958, PRO, PREM II/5084.

43 IRD: origins and establishment of the foreign office information research department, 1946-I948 (London, I995), p. 8.

${ }^{44}$ Murray, 8 Oct. 1949, PRO, FO irio/267.

${ }_{45}$ Murray to Sheridan, i9 July i949, PRO, FO II Io/267.

${ }^{46}$ Paul Lashmar and James Oliver, Britain's secret propaganda war, I948-I977 (Stroud, I998), p. 3 I.

${ }^{47}$ Sheridan to Murray and Watson, 4 Aug. 1949, PRO, FO IIIo/267. 
The proposal aroused strong views within the foreign office. J. W. Russell, expressing the views of the western department, felt 'bound to go on the record as being on the whole against the scheme', believing that 'considerable further thought' was needed before any action was taken. ${ }^{48}$ Upon making a 'cold calculation of the publicity value of each of the visitors on his return', S. H. C. Woolrych, who had himself served at SOE's training establishment Beaulieu before joining IRD, concluded that 'merely as ex-partisans I fear that their value will be very small for the money which will be expended ... It is to be feared that a war-time connection is a rapidly dwindling asset. ${ }^{49}$ While discussion continued, Gordon Lett, who had made a significant contribution to Italian resistance and had been in contact with SOE during the war, and was by this point working at the British Press and Information Office in Bologna, attempted to move the scheme along, sending IRD a list of suitable ex-partisans for the visiting party. ${ }^{50}$ His initiative was jumped upon as an attempt 'to fix arrangements direct instead of through his immediate masters' by those opposed to the visit in London, where discussion had moved on to whether the word 'partisan' was irredeemable, a foreign office official opposed to the visit arguing that:

the word 'partisan' in the Italian mind now suggests a Communist. If the Press announces that a party of partisans is being entertained here the Italian public will undoubtedly think that it is some sort of Fellow Travellers stunt, and ... it will seem very queer indeed if the part played by British officials gets known. ${ }^{51}$

Murray contacted the British embassy in Rome in October to ascertain the views of the ambassador, Sir Victor Mallett. ${ }^{52}$ Mallett remained in favour of the proposal, although he expressed concern that 'there should be no suggestion of His Majesty's Government taking a hand in the matter' ${ }^{53}$ Despite this conditional support, Russell remained unconvinced that the visit would be of any use. Pointing to 'the generally accepted agricultural thesis that you cannot sweeten a cart-load of muck with a pot of marmalade', he also questioned the potential publicity value of the scheme, arguing that 'however discreetly the official boosting is concealed, I feel sure that the Italians will see the hand of His Majesty's Government behind the scenes. Even if the screen of the "Special Forces Club" is effective, surely no one in Italy imagines it to be anything more than a false front organisation of the British Intelligence Service? ${ }^{54}$

${ }^{48}$ J. W. Russell, in Aug. I949, PRO, FO in 1 /267.

49 S. H. C. Woolrych, II Aug. I949, PRO, FO IIIo/267. For further information on Woolrych's time with SOE, see Cyril Cunningham, Beaulieu: the finishing school for secret agents (Barnsley, I998), pp. $56-62$.

${ }^{50}$ Lett to IRD, I7 Sept. I949, PRO, FO IIIo/267. See Lett's obituary in the Independent, i6 Oct. I989, p. I8 (written by M. R. D. Foot).

${ }^{51}$ A. D. F. Pemberton-Pigott, I2 Oct. I949, PRO, FO IIIo/267.

${ }^{52}$ F. R. H. Murray to J. D. Ward, 24 Oct. I949, PRO, FO ${ }_{\text {II I } / 295 .}$

${ }_{53}$ J. A. Pilcher to Ralph Murray, 29 Dec. I949, PRO, FO IIIо/295.

${ }^{54}$ Minute, J. W. Russell, 9 Jan. I950, PRO, FO iı Io/295. 
With a final decision no closer, Peter Wilkinson entered the debate. Wilkinson, who had served with SOE throughout the war and joined the foreign office upon its demise, drew upon his personal experiences with the Italian partisans, pointing out that the Communist partisan groups 'certainly included a fairly large number of the rank and file who were not convinced communists'. As such, he believed that 'Provided the invitations did not include persons who were known to-day to be active communists, I can see that the visit might be profitable.' Wilkinson proposed writing to Mallett once again, setting out the various arguments for a final, informed decision to be made.$^{55}$ Fully appraised, Mallett remained in favour of the visit going ahead, provided that 'the ex-partisans should be invited by the Special Forces Club and should, as far as possible, be persons well known to members of the Club ${ }^{56}$ His earlier concern that the hand of the government would be detected pulling the strings was now considerably diminished:

Since I understand that the present chairman of the Special Forces Club is Commander G. A. Holdsworth, who formerly commanded No. I Special Force in Italy, it seems to me that it would be difficult for any critic to argue that there was anything unnatural in the Club, during his tenure of office, inviting representatives from among his former associates. $^{57}$

Sheridan proceeded to meet with Holdsworth, who was 'whole heartedly in favour of giving any assistance he can to such a visit', and agreed to organize 'a Reception Committee of S.O.E. officers who were members of Special No. I. Force, which he commanded, in Italy' ${ }^{58}$

Despite such apparent progress, the scheme soon stalled. Lett, 'despairing of getting official support', instead made arrangements with the Anglo Italian Society for his selection of ex-partisans to visit Britain. He personally provided $£ 75$ for the trip, while the British Italian Society contributed a further $£ 75{ }^{59}$ IRD proceeded to debate whether they should provide any financial support for the visit, which had now been taken out of their hands. Wilkinson, following consultation with Murray, argued that 'the object of this operation is to show the former partisans in Italy that they have not been forgotten. That is all. We are therefore prepared to offer a small subsidy.' A contribution was duly made 'using a suitable cut-out'. ${ }^{60}$ The visit finally went ahead between ${ }^{13}$ October and 4 November, being organized "jointly by the British-Italian Society in London and the Special Forces Club who shared expenses and received an indirect subsidy of $£ 75$ from I.R.D. funds'. The party had consisted of five Italian expartisans, all of whom were described as 'anti-Communist and very pro-British'.

${ }^{55}$ Minute, Wilkinson, 21 Jan. 1950, PRO, FO I I /295. For further details of Wilkinson's time with SOE, see his Foreign fields: the story of an SOE operative (London, 1997).

${ }_{56}$ Minute, Butler, 29 Apr. I950, PRO, FO II Io/295.

${ }_{57}$ Mallet to Warner, 25 Apr. I950, PRO, FO in Io/295.

${ }_{58}$ Minute, Sheridan, I2 May i95o, PRO, FO Ii $10 / 295$.

${ }^{59}$ Minute, Wilkinson, I2 Oct. I950, PRO, FO 1 I $10 / 295$.

${ }_{60}$ Minute, Wilkinson, 18 Oct. 1950, PRO, FO In $10 / 295$. 
It was recorded that 'publicity given to the visit was good. The party's activities were well covered by the B.B.C.', and also received radio and press coverage in Italy. In conclusion, it was pointed out that 'it will be seen that what was quite a small and not very expensive operation achieved good results', measured in terms of 'publicity; strengthening Anglo-Italian ties of friendship; possible counteraction of Communist control of the political force of Italian ex-partisan associations; sowing seeds for future similar exchanges, possibly of workers' ${ }^{61}$ Such concern and action provides a useful backdrop against which the decision to commission research on SOE should be viewed, and lends credence to the argument that $\mathrm{SOE}$ was a useful means whereby Communist propaganda could be countered.

\section{V}

Serious discussion of a possible SOE history appears to have begun in I959, with the establishment of working party to consider whether such an account should be written. Meeting on 2 April at the foreign office, SOE's interests were represented by three of SOE's most influential figures, Gubbins being joined by Brigadier R. E. Brook, who had directed western European operations, and Brigadier R. H. Barry, originally head of SOE's operations section and later chief of staff. The report of the meeting made the argument for an official work on SOE, based on long-term considerations, clear:

The former officers agreed that the production of an authoritative account of S.O.E. activities under official auspices was both feasible and desirable. Such a work would meet the pressure in responsible academic circles abroad for an authentic account of S.O.E.: would help to remind our Allies of the indispensable role this country had played as a base for their indigenous resistance movements: and would set our contribution in its proper place and perspective against the general background of the war. There was thus a strong case for the production of a history, quite apart from the desirability of refuting current misconceptions. ${ }^{62}$

While there was certainly more to the publication of a history than a knee-jerk reaction to allegations circulating in recent SOE-related literature, it was hoped that such a work could place these in perspective, although it was strongly emphasized that any book should not rise to the bait and tackle them head-on: 'The account should be an objective one, and should not seek directly to refute the misrepresentations in some recent books.' The working party met again during May, at which point Professor Mackenzie was invited to give his views on the structure an official work on SOE should take, and to suggest a possible author. Mackenzie 'argued strongly' for 'a broad and not very detailed survey of the picture as a whole', an approach which had the added advantage of reducing

${ }^{61}$ Mr Butler, 'Visit of Italian ex-partisans to the U.K. between I3th Oct-4th Nov I950: summary of the visit and results', 2 Jan. I95I, PRO, FO iा Io/295.

${ }^{62}$ Official history of SOE: further report by a working party, 22 May I959, PRO, T 220/I388. 
'the difficulty of having to deal with the parts played by individuals'. On the question of an author, Mackenzie recommended that the working party should approach Oxford University, 'where there are two groups working on contemporary history, one centred on St Anthony's College and one on Nuffield College'. 63

Perhaps the most significant indication of foreign office support for the project can be seen when the cabinet office raised the inevitable question of money. Hale wrote to the cabinet secretary, Sir Norman Brook, noting that as potential authors were being considered 'the time has come to face the issue whether the Parliamentary and financial responsibility ... should be taken by us or by the Foreign Office'. Hale noted that Trend (who, despite having moved to the post of third secretary at the treasury, continued to involve himself with the matter of the SOE history) was concerned 'at going any further with this matter unsettled', and pointed out that similar concern had also been expressed by the foreign office R. W. J. Hooper, head of the permanent under-secretary's department, agreeing that it was 'time to face this question'. Hale admitted that, as an official history, it appeared reasonable for the cost to be borne by the cabinet office, but went on to argue that 'The pressure to write this history comes from the Foreign Office', and as such was led to the conclusion that the foreign office should take full responsibility for it. $^{64}$

Upon reading Hale's minute, F. A. Bishop, deputy secretary to the cabinet, wrote to Brook expressing his concern at the path events were taking. $\mathrm{He}$ emphasized his view that it was 'quite wrong to produce an Official History', believing that this:

would stimulate, rather than dispose of, the bitter controversies about some of the personalities involved. Of course 'responsible academic circles abroad', and no doubt here, would like to have the story; but we must admit that what we would be doing would be to give in to the political pressure of people like Dame Irene Ward. ${ }^{65}$

Bishop was sceptical about the prospects of "selling" the responsibility for this project to the Foreign Office', believing it 'unlikely that they would agree to accept Parliamentary and financial responsibility'. Even if the foreign office agreed to take it, Bishop believed that 'many of the repercussions would fall on us, as generally responsible for War Histories'. Bishop firmly believed that 'there should not be an Official History of S.O.E. if we can possibly avoid it'.66

It is arguable that Bishop's bias against the book clouded his judgement. He certainly appears to have underestimated foreign office interest in the project: Dean wrote to Brook on I7 July, noting that the foreign office would 'be prepared in principle' to take responsibility for financing the work, 'on the assumption that our further enquiries show that the project is practicable and Ministers agree that

${ }^{63}$ Ibid. $\quad{ }^{64}$ Hale to Brook, 22 May i959, PRO, T 220/I388.

65 Bishop to Brook (copies to Trend and Hale), 25 May i959, PRO, T 220/I388. $\quad{ }^{66}$ Ibid. 
it is desirable, and on the understanding that its acceptance as a charge on our vote would not be at the expense of any of or commitments'. Fully aware of the 'difficulties and dangers' inherent in the proposal, Dean believed that, on balance, 'the advantages outweigh the disadvantages'. ${ }^{67}$

That foreign office concerns went deeper than a desire to counter negative publicity incurred from recent books on SOE can be seen again in a draft letter from the foreign secretary to Dame Irene in May 1960, which offers some insight into foreign office thinking:

I know it would please some individuals, particularly those who feel that the books hitherto published have given a distorted picture of what really happened, and that unless there is an authoritative account of the part played by this country, our contribution to European resistance is likely to be misrepresented. But I have to think of the national interest; and I have to think of it in terms of the present and future rather than of the past ... Some of our activities, moreover, although justifiable in war, could cause us a lot of embarrassment if publicly admitted now. Then I have to consider the effect on our relations with our wartime allies, and whether the inevitable revival of old controversies and re-opening of old wounds would not do more harm than good. ${ }^{68}$

The main foreign office concern, then, was focused not on the irritation of 'some individuals' regarding recent publications, but rather on the question of the relative advantages and disadvantages to be had on the broader European scene, should a volume on SOE be commissioned for publication.

The decision to go ahead with the writing of a history, without any guarantee of its publication, was officially reached at a meeting held on I8 May ig6o, although by this point the commission was a fait accompli ${ }^{69}$ Dean wrote to Trend on 3 May, noting that 'the more we think about it the more we are forced to the conclusion that the only way to discover whether one can be written is to try and write it' ${ }^{70}$ In early November, Wilkinson wrote to M. R. D. Foot, asking whether he would agree "to prepare a history of the activities of the Special Operations Executive in France during the 1939-45 War based on official material which would be made available'. ${ }^{71}$ Foot replied immediately, stating that he would

${ }^{67}$ Dean to Brook, I7 July I959, PRO, T 220/ I388. Trend wrote to Dean on 4 Aug., with a 'word of warning', noting that the treasury could not guarantee extra money for the work, stressing that any discussions should 'be as non-committal as possible until we know whether you are so keen on the enterprise that you wish to press for its inclusion in your Vote even at the expense of some other undertaking' (Trend to Dean (copy to Brook), 4 Aug. I959, PRO, T 220/I388). No record of the discussions that took place at Oxford appears in the released papers. Dean later recorded that 'Hooper did have some very tentative discussions with William Hayter at New College, but they did not get very far as at that moment most of the people who might have been expected to take an interest were heavily engaged in the Chancellor's election' (Dean to Trend, 3 May i96o, PRO, PREM i /5084).

${ }^{68}$ Draft letter to Dame Irene Ward, DBE, MP, from the secretary of state, foreign office. Undated, PRO, PREM II/5084.

${ }^{69}$ SOE History - Meeting, i8 May i96o, PRO, PREM II/5084.

70 Dean to Trend, 3 May i96o, PRO, PREM i //5084.

71 Wilkinson to Foot, 7 Nov. I96o, PRO, PREM ir/5084. 
'gladly' undertake the task, ${ }^{72}$ and officially began work on the history on 9 November ig6o. ${ }^{73}$

Rather than taking part in the decision-making process, Dame Irene was informed when the decision had been made. In May, Trend wrote to Dean expressing his belief that it would be unwise to inform Dame Irene 'that we are putting a "trial run" in hand', ${ }^{74}$ a decision which was reversed in September. Edward Heath, lord privy seal with foreign office responsibilities, wrote to Dame Irene, noting that 'For your own information - and nobody else outside this Office, the Cabinet Office and the Treasury is being told of this - we have come to the conclusion that ... we must have a pilot project on one area of S.O.E. operations. ${ }^{75}$ Heath emphasized that the decision whether or not to publish the resulting draft was not one which could be rushed:

This is an exceptionally tricky problem and one which must be turned over and examined from all sides ... It would be a much graver abdication of responsibility on our part to take the easy way out and agree to publication of a History here and now, than it would be to err on the side of caution and postpone a decision about publication for another two years or so.

Heath offered Dame Irene a deal: 'I am arranging that you should be kept informed of progress in general terms', in return for which he asked if she 'could forbear from prodding us about it in public ${ }^{76}$

\section{I}

The decision to commission an official history of SOE was no more the direct consequence of Dame Irene's campaign than it was an example of government openness. A rather more influential factor in the decision-making process concerned the perceived need for greater attention to be drawn to Britain's relationship with resistance movements during the war, and while Dame Irene should not be wholly omitted from the decision, her role needs to be placed in

72 M. R. D. Foot to under-secretary of state, foreign office, 7 Nov. I96o, PRO, PREM i I/5048. Wilkinson later elaborated on events leading to Foot's employment at a Witness Seminar: 'I rang up William Deakin at St Antony's, Oxford, and asked whether he had anybody who he could recommend to undertake this work, and he recommended Michael Foot, said that he was about to undertake the Gladstone diaries but he thought he had six months free beforehand, in which case he could easily polish this off! So I asked Michael to come and see me and it seemed to me he was ideally suited to the job, so we went straight over to see Sir Burke Trend, who also agreed that Michael was ideally suited to the job and offered it to him across the table. I then obviously gave instructions that he was to be given full access to anything that was available, and it went from there' (Christopher Andrew and Richard J. Aldrich, eds., 'The intelligence services in the Second World War', Contemporary British History, I3 (1999), pp. I30-69, at p. I45).

73 Foot was contacted by Wilkinson on 22 Nov., who told him that 'For the purpose of payment of your monthly fee, you are deemed to have started work on November 9, I960' (Wilkinson to Foot, 22 Nov. i96o, PRO, PREM ir/5084). $\quad{ }^{74}$ Trend to Dean, i m May ig6o, PRO, PREM ir/5o84.

75 Ted Heath to Dame Irene, 2 Sept. I960, Bodleian Library, Dame Irene Ward papers, MS.Eng.c.6976, fos. $76-7$. 76 Ibid. 
context. The importance of Dame Irene's involvement is to be found in the manner in which she helped to fulfil the criteria for the release of information on SOE set down some fifteen years earlier by the JIC: that there needed to be evidence of a demand for information about SOE both at home and abroad. While there is no evidence of direct JIC involvement in the immediate run up to the ig6o commission, by vocally representing the need for official information on SOE to be made available at home, Dame Irene effectively strengthened the case of those who believed that the publication of official information on SOE was necessary, not to appease a band of investigative journalists, but to address the issue of Britain's involvement in wartime resistance in Europe, and to counter the subsequent interpretations of resistance activity that had emanated from both the Soviet Union and America. 